\title{
System Dynamics Based Model for the Nachchaduwa Reservoir in the Malwathu Oya Basin, Sri Lanka
}

\author{
R.D.T. Kaushalya and K.D.W. Nandalal
}

\begin{abstract}
Though Sri Lanka is a water rich country where many water resources development projects have been implemented, the country still very often faces many issues due to water scarcity. By improving the management of existing water resources development projects such issues could be addressed. The irrigation area coming under the Nachchaduwa Reservoir Scheme in the Malwathu Oya Basin has encountered severe water scarcities in the recent past. This paper presents a system dynamics based simulation model that will help in making decisions for managing the Nachchaduwa Reservoir for fulfilling the water requirements of its irrigation area. The model was developed using system dynamics concepts and the software used was Vensim Professional. The advantage of system dynamics modelling is its ability to model many different sectors such as water quantity, population, agriculture and economy using one single model making it possible to look at all sectors using the same model . The model developed for the Nachchaduwa Reservoir System comprised of the above sectors and was used to investigate several optional operation patterns of the system. Four different operational patterns were considered based on crop types and cropping areas. Initially, the developed model was tested for its applicability and thereafter it was used to determine the most suitable cropping pattern. The results indicate that the patterns consisting of $100 \%$ paddy during the Maha Season and $50 \%$ paddy and $50 \%$ maize during the Yala Season as the most suitable cropping patterns for the two seasons. The model also showed that the temporary increase in the population by the pilgrims and tourists visiting the area during festive seasons affects the amount of water available for crops.
\end{abstract}

Keywords: System Dynamics Simulation, Vensim Software, Nachchaduwa Reservoir

\section{Introduction}

Water is a resource essential for the survival of life on the planet Earth. Due to the rapid increase of population, development of industries, urbanization, change of agricultural patterns, industrial pollution, climate change etc., water scarcities have been experienced all over the world. By 2025, 1.8 billion people are expected to be living in countries or regions with absolute water scarcities, and two-thirds of the world population could be undergoing water stress conditions [1]. Therefore, it is vital that we manage the existing limited water resources in the world in an appropriate and sustainable manner to cater to their demand satisfactorily.

Sri Lanka is regarded as a water rich country that receives monsoon, convection and depression rainfall throughout the year. The annual average rainfall varies approximately from $900 \mathrm{~mm}$ in the dry zone of the country to $5000 \mathrm{~mm}$ in the wet zone. Its surface water system consists of rivers, lakes and man-made reservoir systems and groundwater is used in some parts of the country. Water is used in the country for drinking, industries and agricultural purposes and the agriculture sector consumes the highest quantity of water[2].

Though Sri Lanka is considered as an island rich in water resources, diverse locations in the country face water scarcities at different times in a year. In addition to the rapid increase in the population and industrial growth which increase the demand for water, the inefficient management of the available water resources is also responsible for these scarcities. Besides, the availability of water and the increase in the demand for water, issues such as the economic value of water based on agricultural products

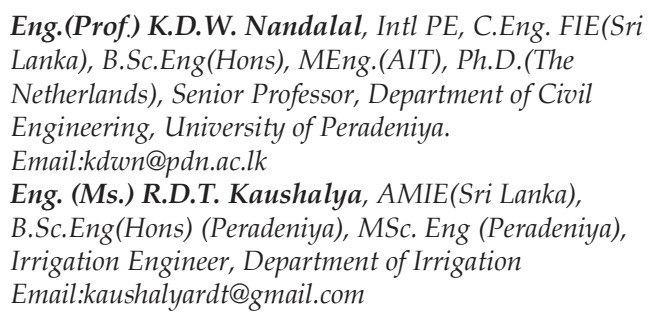


need to be considered in the management of water available within an area or a river basin.

There are many studies done to assist in the management of water resources by considering the availability of water and the demand for it $[3,4]$. However, not many studies have been done on the importance of considering population increases, industrial changes, and economic value of water when making water management decisions. This paper presents a study carried out to show the possibility of making water management decisions by considering water quantity both in space and time along with population changes and economic gains of the decisions made. The decisions are made based on a comprehensive model developed using principles of system dynamics (SD), a well-known mathematical modelling approach available to study the behaviour of dynamic systems.

The SD is a complex method of system description that facilitates the analysis of alternative decision policies on system behaviour [5, 6]. The development of a SD model includes the following steps in the order indicated:

(a) Understanding the system and its boundaries;

(b) Identifying the key variables;

(c) Representing the physical processes in mathematical terms;

(d) Simulating the model to understand its behaviour; and,

(e) Interpreting the simulation results for efficient decision-making.

The application of SD modelling for global, regional and basin-level water resources systems has proven to yield remarkable results, though not many such applications are found in the literature. In the global models such as TARGETS [7] and World Water [8], the water resources sector has been linked to other pertinent development and policy issues related to demography, economy, energy, pollution and non-renewable resources. The SD modelling approach has been used for the analyses of Sri Lanka's water resources on a country scale integrating water, agriculture and economy sectors [9]. The use of SD modelling for the resolution of conflicts over water has also been demonstrated [10].A basinlevel model ErhaiSD [11] has been developed to manage the environmental issues of the Lake ErhaiBasin in China. A water resources SD model- WRSD - [12] for the Yellow River Basin in China has been developed to analyse the sustainable water resources management in the basin. The management of water resources in the Manas River Basin considering the interaction of the latter with social, economic and political systems had been studied based on a SD based model [13]. Similarly, SD modelling has been used in the economic assessment of water supply and demand strategies [14], analysis of socio-economic impact of environmental flow [15] etc.

Although SD modelling of water resources systems has been practiced in some other countries, its use for basin scale modelling of water resources in Sri Lanka is not reported. This paper presents a comprehensive SD based model built for the management of the irrigation system of Nachchaduwa Reservoir located in Malwathu Oya Basin shown in Figure 1. The model incorporates, in addition to the available water resources, socio-economic aspects associated with the system. The Malwathu Oya Basin, which has been having a well-connected reservoir and village tank cascade system since ancient times still faces water scarcities during dry seasons. It also experiences high floods during rainy seasons. The proper management of the water resources system in the basin may help to minimize the negative impacts due to droughts and floods.

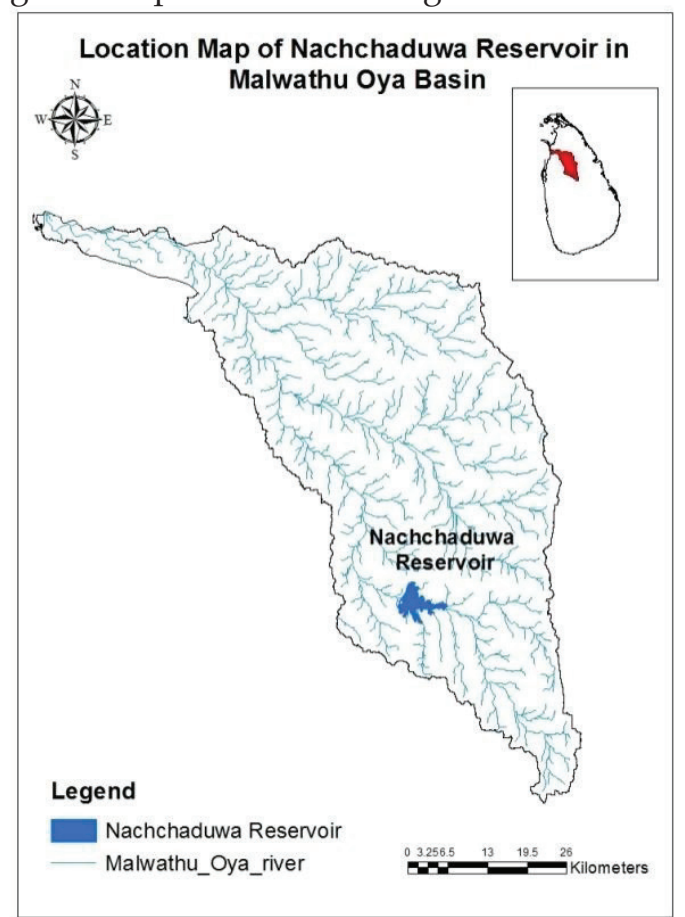

Figure 1 - Malwathu Oya Basin and Nachchaduwa Reservoir

The water available in the dry zone has failed naturally to satisfy the irrigation demand of 
both Yala and Maha Seasons. The Yala Season rainfall in the Anuradhapura District, where the Nachchaduwa System is situated has shown a significantly decreasing trend while the Maha Season rainfall has significantly increased[16]. Therefore, it may be necessary to change the traditional crop pattern and cropping calendar in the Yala Season while practicing proper water management practices such as increasing the reservoir storage during the Maha Season.

In this study, the SD based model for the Nachchaduwa Water Resources System was developed using Vensim Professional (Ver5.4) simulation environment [17]. The model comprising surface water use, population, agriculture and economy sectors of the system was used to derive the optimum operational patterns for the Nachchaduwa Reservoir.

The interrelationships between different components were mathematically modelled considering the 'surface water use' component as the main sector for analysing the dynamic variation of each variable. Four scenarios were analysed considering temporal and spatial variations of the crop type to select the crop pattern appropriate to the irrigable extent of Nachchaduwa Reservoir while optimizing simultaneously surface water use, land use and economy components. One of the scenarios was analysed considering the effect of the variation of the population towards the 'surface water use' component by assuming a $50 \%$ increase in the population due to the migratory population that visit Anuradhapura City.

\section{Methodology}

\subsection{Data Collection}

Data required for the study were collected from the Department of Irrigation, Department of Census and Statistics, Department of Meteorology, Hector Kobbekaduwa Agrarian Research and Training Institute, Climate Resilience Improvement Project and Mahaweli Authority of Sri Lanka. Qualitative data were collected from past project reports, topo-sheets and shape files. Quantitative data such as rainfall data, inflow data, crop data, reservoir parameters, population data, land use data, economic data etc., were obtained from the organizations mentioned above.

\subsection{Formulation of the Simulation Model}

The SD based Nachchaduwa Reservoir System model comprises of four sectors, viz., surface water, population, agriculture and economy. The surface water sector of the Nachchaduwa Reservoir System is the main component of the model. The interrelationships among the sectors were modelled considering feedbacks in a dynamic environment as shown in Figure 2. The model was run from 2005 Yala Season to 2015 Yala Season on a monthly basis.

\subsection{Surface Water Component of the Model}

The basic structure of the 'surface water' model was based on the water budget. Temporal variation of reservoir inflow, storage, outflow and spill were modelled. Characteristics of the Nachchaduwa Reservoir are given in Table 1.

\section{Table 1 - Nachchaduwa reservoir} characteristics

\begin{tabular}{|l|r|l|}
\hline Full supply level (FSL) & 101.70 & m MSL \\
\hline High Flood Level (HFL) & 102.31 & $\mathrm{~m} \mathrm{MSL}$ \\
\hline $\begin{array}{l}\text { Minimum operating level } \\
\text { (MOL) }\end{array}$ & 95.58 & $\mathrm{~m}$ MSL \\
\hline Storage at MOL & 2.1 & MCM \\
\hline Storage at FSL & 58.0 & MCM \\
\hline Storage at HFL & 67.2 & MCM \\
\hline
\end{tabular}

The main relationship involved in the "surface water" component of the model given in Figure 2 is the water balance which is shown below.

$\frac{d}{d t}($ Nachchaduwa Storage $)=$ Inflow -

Evap - Outflow - Spill

Reservoir storage variation is confined to the storage range within the maximum and minimum reservoir volumes. If the reservoir is full and if it receives further inflow, the excess water will spill out. The amount of water supplied to meet the irrigation demand, drinking water demand, and mandatory downstream release were considered as the outflow. Evaporation loss from the reservoir surface is considered in the reservoir water balance. Pan coefficient was assumed as 0.8 . Irrigation demand was calculated as a function of the crop water demand and drinking water demand was calculated as a function of the population and per capita water demand of $120 \mathrm{l} / \mathrm{head} /$ day. Seepage loss was neglected in the calculations. 
Population data of the census years 2001 and 2012 available at the divisional secretariat divisions (DSD) located in the Malwathu Oya Basin were used in the study. For the Nachchaduwa Reservoir command area which is in the Anuradhapura District, the population growth rate used was $1.38 \%$ [18]. By using the population data of the years 2001 and 2012, an yearly exponential growth pattern of the population was developed. Monthly populations were calculated by interpolating between adjacent years.

\subsection{Agriculture Component of the Model}

Irrigation water requirements on a monthly basis were considered in the agriculture component of the model. Paddy is the major crop grown in the dry zone of Sri Lanka during the Maha Season. Various types of cash crops are grown during the Yala Season along with paddy, which covers a lower extent than the cash crops due to the non-availability of sufficient amounts of irrigation water. The agriculture component of the model was developed considering two types of crops; paddy and other field crops (OFC). There are various types of OFC that grow in Sri Lanka during Maha and Yala Seasons such as kurakkan, maize, sorgthum, meneri, green gram, cowpea, soya beans, ground nuts, chillies etc. The data on the cultivation extents for 2014/2015 Maha Season and 2015 Yala Season extracted from the records of the Department of

Census and Statistics showed that about 50 percent of the area has been used for maize. Thus, maize was used in the model to represent.

Monthly water demands for paddy and maize were calculated to determine their irrigation requirements. Water demands were calculated using reference crop evapotranspirations, crop coefficients $(\mathrm{Kc})$ and cultivation areas. Crop coefficients for paddy and maize were calculated considering the growth stages of crops and the duration of their cultivations. The extents of past cultivations of paddy and maize were obtained from the records of the Department of Irrigation. Seasonal paddy and maize productions were calculated using cultivated area and yield of crop. The amount of crop harvested from a unit area was considered as the yield of crop. Seasonal yields of crops were calculated based on historical productions and cultivation extents in the Anuradhapura District obtained from the statistical abstracts of the Department of Census and Statistics. The estimated average Maha Season paddy yield was $4570 \mathrm{~kg} / \mathrm{ha}$ and average Yala Season paddy yield was 4498 $\mathrm{kg} / \mathrm{ha}$. Therefore, a season yield of $4500 \mathrm{~kg} / \mathrm{ha}$ was used in the model for both Yala and Maha Seasons of 2005 to 2015. Similarly, the average Yala Season maize yield was $2542 \mathrm{~kg} / \mathrm{ha}$ and the average Yala Season paddy yield was 2486 $\mathrm{kg} / \mathrm{ha}$. Therefore, a season yield of $2500 \mathrm{~kg} / \mathrm{ha}$ was used in the model for both Yala and Maha Seasons of 2005 to 2015.

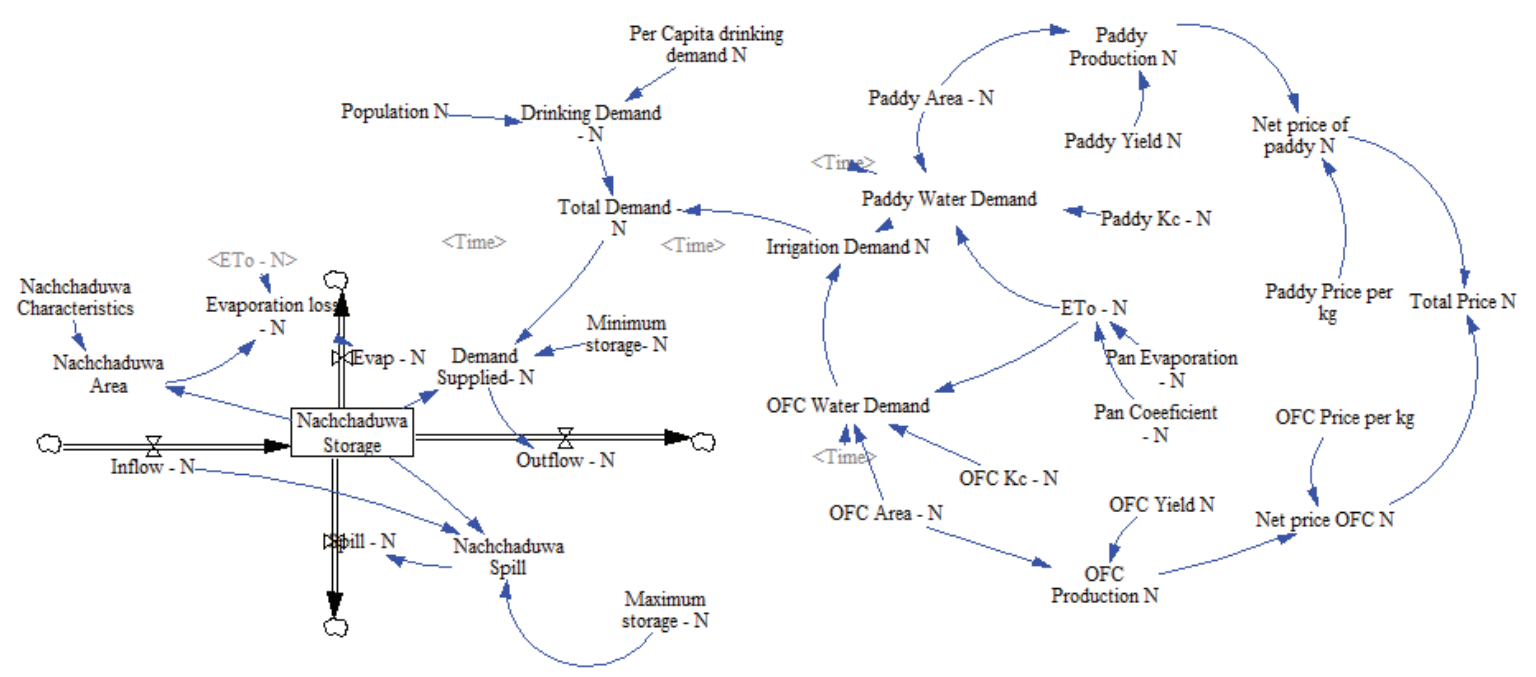

Figure 2 - The SD model for the Nachchaduwa Reservoir System 


\section{6}

Economy Component of the Model

Temporal variations of farm gate price of samba rice per kilogram and farm gate price of maize per kilogram were fed in to the model for investigating the net price variation of both crops during the period from 2005 Yala to 2015 Yala, subjected to variations in surface water, population and agriculture components. There are many rice varieties available in the market. Mostly samba rice is used by people. Therefore, farm gate price of samba rice per kilogram was used for the analysis. Monthly average farm gate prices of maize and samba rice were obtained from the Hector Kobbekaduwa Agrarian Institute.

\section{Analysis and Results}

\subsection{Testing the Model}

Initially, the SD based model developed for the Nachchaduwa Reservoir System was tested for accuracy using reservoir storage. The reservoir storage determined from the model was compared with the actual reservoir storage data obtained from the Department of Irrigation. The results presented in Figure 3 indicate the acceptance of the model.

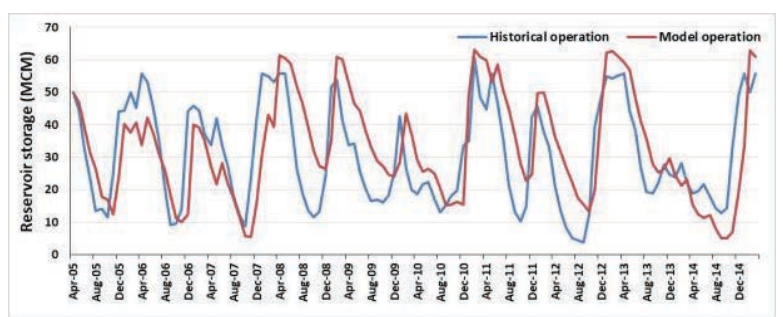

Figure 3 - Calibration of the model

\subsection{Scenario Analysis}

After testing the model for its suitability for simulating the system, five different system scenarios were investigated.

The variations of types of crops and cultivation extents were analysed using these few scenarios. The impact of the population growth /increasing population caused by those who migrate to the Anuradhapura City was analysed under one scenario. The impact of the variability of the population sector and the agriculture sector on the other sectors, namely sector using surface water and economy sector were studied by analysing selected scenarios. The five scenarios studied are described below.
Scenario (a)

Surface water use, agriculture, land use, population and economic conditions are as at present.

Scenario (b):

Paddy is cultivated in the full extent of the irrigable area during both Yala and Maha Seasons

Scenario (c):

Paddy and maize are cultivated in the full extent of the irrigable area during the Maha Season and Yala Season, respectively.

Scenario (d):

Paddy is cultivated in the full extent of the irrigable area during the Maha Season, 50\% maize and $50 \%$ paddy are cultivated during the Yala Season

Scenario (e):

Water demand is increased by $50 \%$ considering the population moving to the Anuradhapura City on pilgrimage and as tourists.

\subsection{Results of the Scenario Analysis}

\subsubsection{Scenario(a)}

This scenario investigates the existing water resources system for the current agricultural practices during the period from Yala 2005 to Maha 2015, i.e., from April 2005 to March 2015. Figure 4 presents the temporal variation of reservoir inflow, storage, outflow and spill of the Nachchaduwa Reservoir.

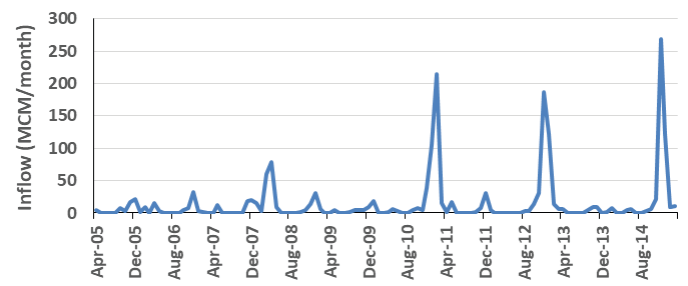

a. Inflow to the reservoir

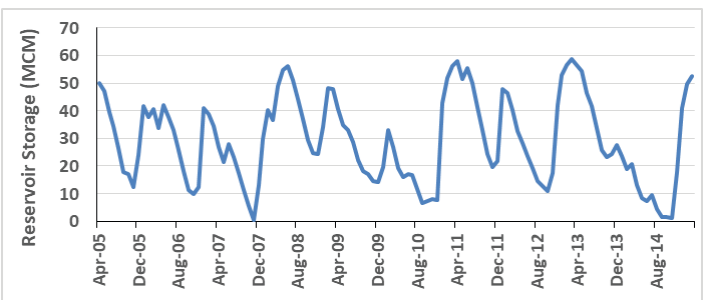

b. Reservoir storage 


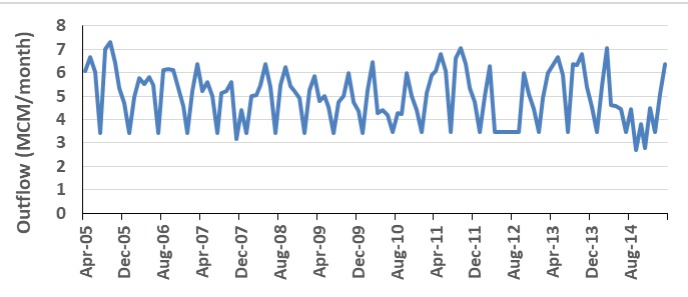

c. Outflow from the reservoir

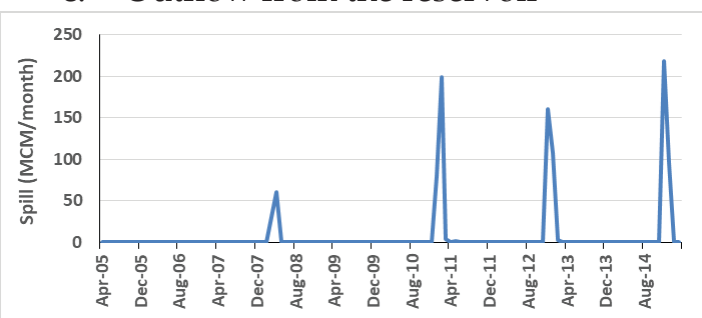

d. Spill from the reservoir

\section{Figure 4 - Inflow, storage, outflow and spill of Nachchaduwa Reservoir}

Reservoir storage has varied depending on the inflow and releases. The increase in the inflow to the Nachchaduwa Reservoir observed during the months of December and April was due to monsoon rains. The maximum monthly evaporation from the Nachchaduwa Reservoir was estimated to be around $2 \mathrm{MCM} /$ month. It is observed that the maximum recorded spill of the reservoir is approximately three times higher than the maximum reservoir storage. This may be due to the high intensity rainfall received during a very short time span. The high sediment deposition in the reservoir has led to the reduction of its effective volume. Thus, the reservoir is unable to store the excess water during high inflow periods.

Figure 5 presents the temporal variation of the drinking water demand and irrigation water demand of the Nachchaduwa Reservoir. This irrigation demand includes both paddy and maize water requirements.

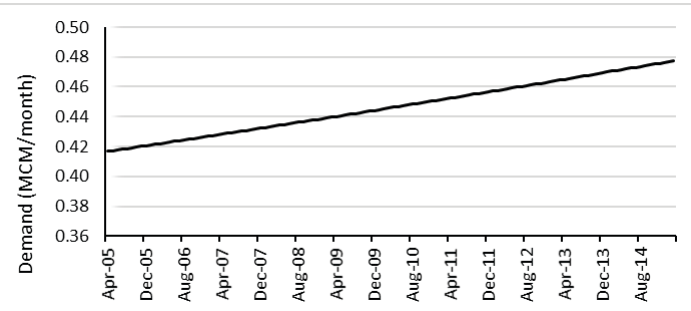

a. Drinking water demand

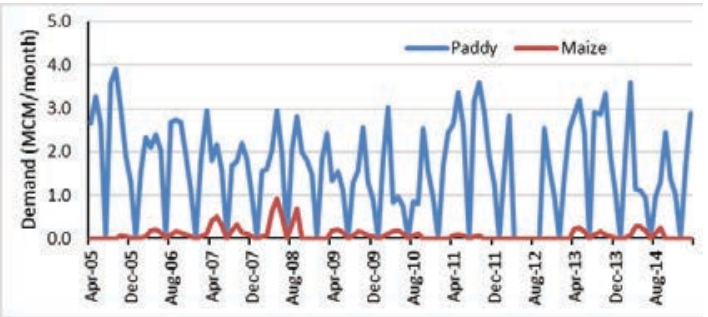

b. Irrigation water demand

Figure 5 - Drinking and irrigation water demands of Nachchaduwa Reservoir

The drinking water demand is very low compared to the irrigation demand. The drinking water demand goes upto a maximum of about 3.9 MCM.

During certain seasons, the farmers do not grow maize or any other OFC. Usually, they grow paddy during the Maha Season since sufficient water is available for paddy from the North East Monsoon Season rainfall. Due to the unpredictable nature of the Yala rainfall, farmers tend to use a lower land area during the Yala season for either paddy along with maize or for only maize. However, it can be observed that the water footprint of maize is less than the water footprint of paddy.

Figure 6 depicts the areas used for paddy and maize during the study period.

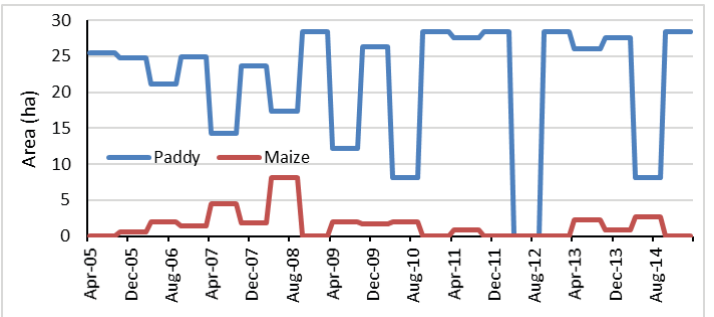

Figure 6 - Paddy and maize areas under Nachchaduwa Reservoir

In the study area, paddy production is relatively higher than maize production. According to the records, the Nachchaduwa Reservoir paddy cultivation partially failed during the 2010 Yala Season and fully during the 2012 Yala Season. Maize cultivation using irrigation water from the Nachchaduwa Reservoir also totally failed during 2010 and 2012 Yala Seasons.

The income (farm gate) received from paddy and maize cultivation during the study period is shown in Figure 7. 


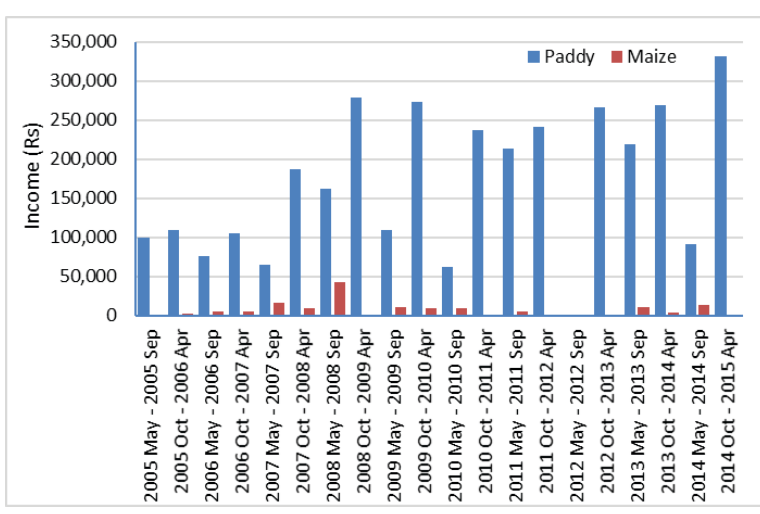

Figure 7 - Price of paddy and maize at Nachchaduwa

According to Figure 7, the income obtained by selling rice is higher compared to that from maize. The estimated yield of paddy is 4500 $\mathrm{kg} / \mathrm{ha}$ while it is $2500 \mathrm{~kg} / \mathrm{ha}$ for maize. Thus, the amount of paddy harvested per unit area is comparatively high. Also, the farm gate price of paddy is higher than that of maize due to high market demand.

\subsubsection{Scenarios (b), (c) and (d)}

Various combinations of paddy and OFC cultivation extents were studied as Scenario (b), Scenario (c) and Scenario (d). Percentage variation of cultivation extents of these scenarios is shown in Table 2.

Table 2 - Paddy and maize cultivation extents of different scenarios

\begin{tabular}{ccccc}
\hline Scenario & \multicolumn{2}{c}{$\begin{array}{c}\text { Paddy } \\
\text { cultivation }\end{array}$} & \multicolumn{2}{c}{ Maizecultivation } \\
\cline { 2 - 5 } & Yala & Maha & Yala & Maha \\
\hline a & $\begin{array}{c}\text { Actual } \\
\text { Extents }\end{array}$ & $\begin{array}{c}\text { Actual } \\
\text { Extents }\end{array}$ & $\begin{array}{c}\text { Actual } \\
\text { Extents }\end{array}$ & $\begin{array}{c}\text { Actual } \\
\text { Extents }\end{array}$ \\
\hline b & $100 \%$ & $100 \%$ & - & - \\
\hline c & - & $100 \%$ & $100 \%$ & - \\
\hline d & $50 \%$ & $100 \%$ & $50 \%$ & - \\
\hline
\end{tabular}

The cultivation extent for each scenario was varied as a percentage. Reservoir system simulations were carried out for these scenarios of different cultivation extents. The resulting reservoir storages, total water demands and total farm gate incomes were studied for each scenario.

The behaviour of the Nachchaduwa Reservoir storage for Scenarios (a) to (e) are shown in Figure 8.

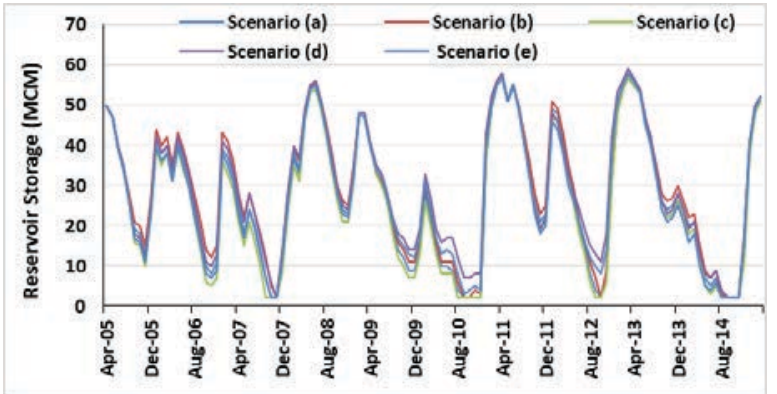

Figure 8 - Variation of Nachchaduwa Reservoir storage for each case

Model simulations for the different scenarios revealed that the cultivation according to Scenario (b) fails in the years 2007, 2010, 2012 and 2014. The cultivation according to Scenario (c) fails in the years 2007 and 2014 while Scenario (d) cultivation fails in the years 2007, 2010, and 2014. Therefore, out of the alternatives investigated, Scenario (c) which grows $100 \%$ paddy during the Maha Season and $100 \%$ Maize during the Yala Season, is suggested as the preferable crop combination for the Nachchaduwa Reservoir Irrigation System.

The total irrigation water demands of the Nachchaduwa Reservoir during the study period for all the scenarios are presented in Figure 9.
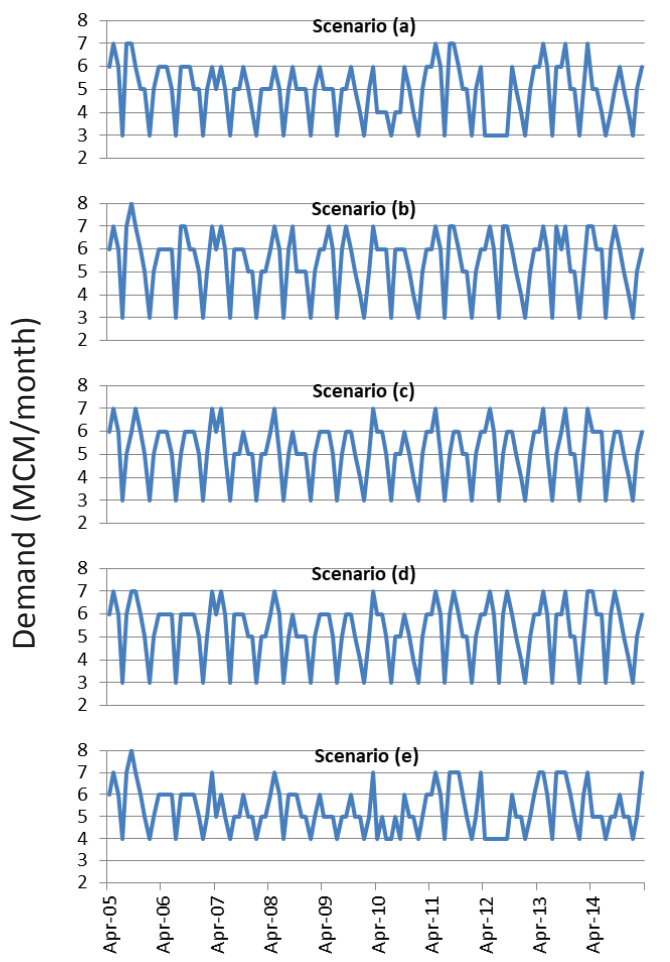

Figure 9 - Total irrigation water demands at the Nachchaduwa Reservoir 
Figure 9 illustrates that the cultivation according to Scenario (b) shows the highest total irrigation water demand. The maximum water demand during the period from 2005 to 2015 is 7.7 MCM in the Maha Season of the year 2005. The maximum water demands in Scenarios (c) and (d) are 7.1 and 7.3 MCM, respectively, both in the year 2012. Scenario (a), which is the actual condition, has 7.3 MCM during the 2005 Maha Season as its highest demand. Scenario (b) shows the maximum water demand during the entire model duration. Scenario (c) shows the minimum water demands. The cultivation of paddy during both Maha and Yala Seasons has caused water scarcity in the drinking water sector and partial crop failure in the irrigation sector due to lack of water. Scenario (c) is observed to be the most suitable irrigation pattern for the Nachchaduwa Reservoir System.

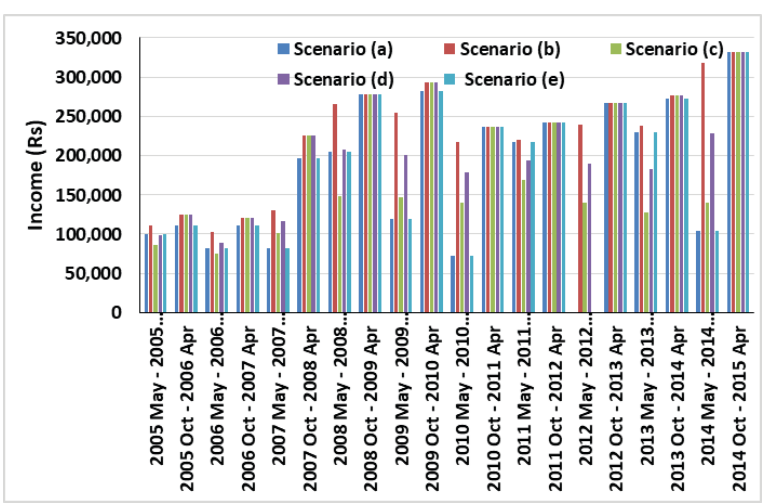

Figure 10 - Total farm gate price of crops cultivated in Nachchaduwa Reservoir System

Figure 10 shows farm gate prices for the five scenarios. The maximum farm gate price is obtained for Scenario (b). Scenario (c) results in lower prices than Scenarios (b) and (d) due to the cultivation of $100 \%$ maize during the Yala Season.

The farm gate price of maize is relatively low compared to the farm gate price of paddy and therefore, growing more maize is not economically suitable for farmers. By studying Scenario (a), it can be observed that there are some years where total cultivation can fail during a year. This may be due to the insufficient amount of water available for crops during the initial growth stage of the crops.

When the water availability for irrigation from the Nachchaduwa Reservoir is considered, it is found that growing $100 \%$ paddy during the Maha Season and 100\% maize during the Yala
Season, (that is Scenario (c)) is the most favourable option. It is also the most favourable option with respect to the total water demand. However, cultivation of $100 \%$ paddy during both Yala and Maha Seasons (Scenario (b)) is the most favourable option with respect to farm gate prices or the total income. Thus, Scenario (c) is the most favourable option with respect to surface water use while Scenario (b) is the most favourable when economy is considered.

Considering all of the above mentioned aspects, the cultivation of $100 \%$ paddy during the Maha Season and 50\% paddy and 50\% of maize during the Yala Season, as in Scenario (d), can be proposed as the most suitable crop pattern for the Nachchaduwa Irrigation System to ensure the sustainability of surface water use as well as the economy.

\subsubsection{Scenario (e)}

This case investigates the impact on water resources in the system by a $50 \%$ increase in the water demand made by the population coming to the Anuradhapura City on pilgrimage and as tourists.

The changes in the population will affect the drinking water demand, resulting finally in changes to reservoir outflows. Thus, the objective was to investigate the impact of increase in the population by $50 \%$ on the reservoir storage while the present irrigation pattern is practiced. That is, Scenario (e) in the present condition (Scenario (a)).

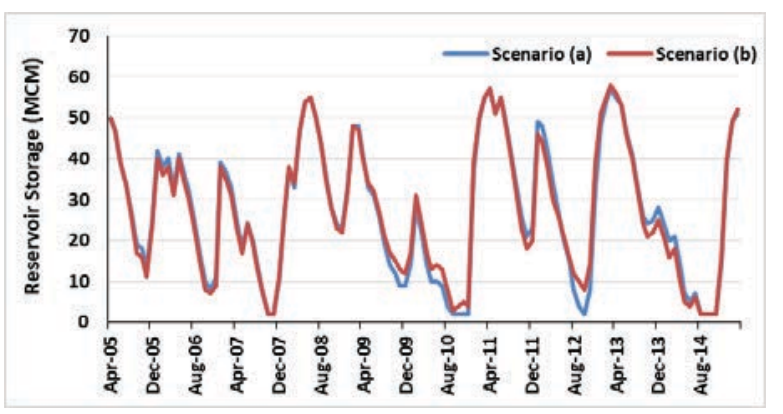

Figure 11 - Nachchaduwa Reservoir behaviour in Scenario (e)

Figure 11 shows the variation of the Nachchaduwa Reservoir storage due to the increase in the population. It is observed that the increase of the population leads to the failure of the reservoir storage during 2007 Maha Season and 2014 Maha Season. The maximum deficiency which occurred during the 2007 Maha Season is 1.9 MCM. Therefore, a 
$50 \%$ increase in the population may create water scarcities in the Nachchaduwa System.

\section{Conclusions}

The simulation model developed for the Nachchaduwa Reservoir System shows the suitability of the Vensim software based system dynamics simulation environment for modelling a complex water resources system considering water, population, agriculture and economy sectors simultaneously, The system dynamics based model developed showed its usefulness in investigating different operational patterns for the reservoir system based not only on water availability but also on economic gains.

The study shows that the most optimum cropping pattern for the Nachchaduwa Reservoir System is to grow $100 \%$ paddy during the Maha Season and 50\% paddy and $50 \%$ maize during the Yala Season in the irrigable area. The results further indicate that the temporary increase in the population in the Anuradhapura City by about 50\% during festive seasons leads to water scarcities in the cultivation areas coming under the Nachchaduwa Reservoir. This study investigated only a few scenarios of cultivation to show the applicability of the system dynamics modelling technique for managing water resources systems. Many more diverse operational plans for the system could be studied using the model to determine the most suitable option.

\section{References}

1. UNESCO, Managing Water under Uncertainty and Risk, The United Nations World Water Development Report 4, UNESCO, 2012, France.

2. Amarasinghe, U. A., Spatial Variation of Water Supply and Demand in Sri Lanka. Proceedings of the National Conference on Water, Food Security and Climate Change in Sri Lanka. Vol. 3: Policies, institutions and data needs for water management. 2009, pp.19-33.

3. Hassan, D., Bano, R., Burian, S. J. and Ansari, K., Modeling Water Demand and Supply for Future Water Resources Management, International Journal of Scientific and Engineering Research, 8(5), 2017, pp.1745-1750.
4. Babel, M. S., Das Gupta, A. and Nayak, D. K., A Model for Optimal Allocation of Water to Competing Demands, Water Resource Management, 19, 2005, pp.693-712.

5. Forrester, J. W., Industrial Dynamics, Cambridge, Massachusetts; MTS Press,1961,pp.340.

6. Sterman, J. D., Business Dynamics - Systems Thinking and Modeling for a Complex World, New York; Irvin McGraw-Hill,2000,pp.640.

7. Rotmans, I. and de Vries, B., Perspectives on Global Change. Cambridge University Press, Cambridge, UK, 1997, pp.463.

8. Simonovic, S. P., World Water Dynamics: Global Modeling of Water Resources. Journal of Environmental Management, 66, 2002, pp.249267.

9. Nandalal, K. D. W. and Semasinghe, B. A. D., System dynamics simulation model for the assessment of water resources in Sri Lanka, In 32nd WEDC International Conference. Colombo, 2006.

10. Nandalal, K. D. W. and Simonovic, S. P., Resolving conflicts in water sharing: A systemic Approach. Water Resources Research Vol. 39,2003.

11. Guo, H. C., Liu, L. Huang G. H., Fuller G. A., Zou R., and Yin Y. Y. A., System Dynamics Approach for Regional Environmental Planning and Management: A Study for the Lake Erhai Basin, Journal of Environmental Management 61, 2001,pp.93-111.

12. Xu, Z. X., Takeuchi, K., Ishidaira, H. and Zhang X. W., Sustainability Analysis for Yellow River Water Resources Using the System Dynamics Approach, Water Resources Management, 16, 2002,pp.239-261.

13. Shanshan, D., Lanhai, L. and Honggang, X., The system dynamic study of regional development of Manas Basin Under the constraints of water resources, Sun Yet-sen university, Guangzhou, Guangdong, China, 2009, pp.1-17.

14. Karamouz, M., Yazdi, M. S. S., Ahmadi, B. and Zahraie, B., A System Dynamics Approach to Economic Assessment of Water Supply and Demand Strategies. Tehran, 2011.

15. Wei, S., System dynamics simulation model for assessing socio-economic impacts of different levels of environmental flow allocation in the weihe River Basin, China. European Journal of Operational Research,2012. pp.248-62. 
16. Gunarathna, M. H. J. P. and Kumari, M. K. N., Rainfall Trends in Anuradhapura: Rainfall analysis for agricultural planning. Rajarata University Journal, 2013, pp.38-44.

17. Ventana Systems Inc, Vensim DSS Version 5.4 User's Manual, 2003.

18. Department of Census and Statistics, Final Report: Census of Population and Housing 2012. Colombo: Ministry of Policy Planning and Economic Affairs Department of Census and Statistics, 2015. 